\title{
SOCIAL DANGER OF DOMESTIC VIOLENCE AND THE NEED FOR REHABILITATION OF ITS VICTIMS
}

DOI: 10.36740/WLek202012232

\author{
Oksana 0. Volodina, Viktoriia V. Haltsova, Sergiy 0. Kharytonov \\ YAROSLAV MUDRYI NATIONAL LAW UNIVERSITY, KHARKIV, UKRAINE
}

\begin{abstract}
The aim: To investigate the social danger of domestic violence, find out its principal manifestations, consequences, and impact on women and minors' health. Based on the acquired knowledge, to suggest ways to overcome this problem, which will minimize the consequences of domestic violence.

Materials and methods: The authors studied and analyzed international legal acts, Ukraine's legislation, and scientific publications on domestic violence. The method of statistical processing of analytical data of the World Health Organization (hereinafter -WHO), the Institute of Demography and Social Research at the request of the UN Population Fund, the Ministry of Social Policy of Ukraine, the Ministry of Internal Affairs and the Prosecutor General's Office of Ukraine (for 2017 - first half of 2020) were used. A comparative method of research was useful in comparing the number of cases of domestic violence in Ukraine and Europe during the COVID-19 pandemic.

Conclusion: It is concluded that domestic violence is a socially dangerous act that negatively affects all family members, as it causes significant damage to health and life. The most dangerous are the consequences of domestic violence on the physical and mental health of women and minors, who are particularly vulnerable to this negative manifestation. Rehabilitation is said to help minimize the effects of domestic violence, restore the physical and mental health of victims, and return them to normal social life.
\end{abstract}

KEY WORDS: family, criminal offense, victim, physical and mental health

Wiad Lek. 2020;73(12 p. II):2895-2901

\section{INTRODUCTION}

During the Second World War, there were mass and serious human rights violations, so the question arose about their protection after its end. Therefore, the world community has adopted several international acts to protect human rights and freedoms. In particular, the adoption of the UN Universal Declaration of Human Rights (1948) and enshrining in Art. 1 principle, according to which "all people are born free and equal in dignity and rights." Of course, the protection of fundamental human rights and freedoms and the adoption of international instruments in this area is an important step, but the efforts of all states must be directed not only to guarantee but also to protect and defend them.

An integral part of the Institute for International Protection of Human Rights is the principle of equality between women and men, the prohibition of any discrimination on the grounds of sex. The fight against women's discrimination takes place in such areas as politics, economics, education, and family. To this end, many international instruments have been adopted to respect equality between women and men, including: the UN Declaration on the Elimination of Violence against Women (1993); Optional Protocol to the United Nations Convention on the Elimination of All Forms of Discrimination against Women (1999); Council of Europe Convention on Preventing and Combating Violence against Women and Domestic Violence (Istanbul Convention) (2011). A number of UN Security Council Resolutions have also been adopted: №
1325 on women, peace, and security, reaffirming the idea of protecting women and enhancing their role in conflict prevention and resolution (2000); № 1960 on combating sexual violence in the context of women's issues, peace, and security (2010); № 2106 on the central role of gender equality and the empowerment of women in political, social and economic rights and opportunities in efforts to prevent sexual violence in armed conflict (2013); № 2242 on the need to protect women in conflict situations and give them a more critical role in their prevention and resolution (2015) and others. Nevertheless, in many countries worldwide, the international legal principle of equality of men and women is still violated, one of the manifestations of which is violence against women, in particular, domestic violence. The situation has become especially acute and more frequent during the COVID-19 pandemic in both Europe and Ukraine. Thus, in April 2020, emergency services in Europe received $60 \%$ more complaints from women suffering from domestic violence than a year earlier, according to the World Health Organization [13].

In Poland, domestic violence causes more injuries than car accidents, assaults, or rapes together [11, p. 25]. According to the WHO, $38 \%$ of murders of women in the world are committed by their husbands. However, in some countries, this figure is as high as $70 \%$ of cases [10]. The death toll from domestic violence in France is also alarming. Thus, in 2019, 146 women became its victims (compared to 2018, there were 25 more murders - by $21 \%$ ), and accordingly, 27 men were killed by their partners. Thus, the total number 
of murders by partners in France is 173 people. In general, in $84 \%$ of violent death cases in a couple, the victims are women, mostly of French origin, aged 30 to 49 or older than 70 years. And most often, the crime is committed with a knife or firearm, in $17 \%$ of cases, death occurs as a result of suffocation [28].

However, domestic violence is perpetrated not only against women but also against minors, with more severe consequences than for adults. Back in 1985, at a WHO meeting in Switzerland, it was stated that any intentional or unintentional act against a child by an adult, community, or state is considered child abuse, which further adversely affects the health, physical and psychosocial development of the child [14, p. 44]. According to the WHO, more than one billion children have been affected by various forms of violence worldwide over the past year. Thus, in $75 \%$ of cases, they faced domestic violence: in every third case, they experienced psychological violence, in every fourth physical [7]. Martha Everard, the head of the WHO office in Ukraine, also pointed out the "adverse childhood events" manifested in domestic violence against minors. For example, in the European region, due to minors' domestic violence or abuse, the death rate among children under the age of 15 is 850 per year, with the highest mortality rates in the post-Soviet countries. Therefore, domestic violence is a very serious problem worldwide, one in four children suffers from physical violence and its consequences and one in ten suffers from sexual violence; one in three children suffered emotional abuse at an early age. That indicates that as a result of domestic violence, family members' physical and mental health suffers negative consequences and always needs rehabilitation. In this regard, the representative of the Department of Violence and Injury Prevention of the WHO Regional Office for Europe Dinesh Sethi said that based on WHO data on the effects of domestic violence, each country should develop a strategy to prevent violence and injury, which should be supported by law [7].

Social projects help reduce the number of cases of domestic violence. Positive in this sense is the example of Poland in the implementation of social campaigns such as "I love. I don't hit", "I love. I react", "I love. I don't shout", and "I love. I have time". Social communication itself is an extremely valuable and essential tool in the fight against violence regarding women and children and helps to show that the family is an exceptional value in human life. These programs help to combat violence; support the strengthening of interpersonal relationships; learn to respect order and be tolerant, appreciate kindness and inform about the negative consequences of violence, which can be eliminated with the help of appropriate specialists.

\section{THE AIM}

To investigate the social dangers of domestic violence, to find out its consequences and impact on women and minors' health. Based on the acquired knowledge, suggest ways to overcome this problem, which will minimize the consequences of domestic violence.

\section{MATERIALS AND METHODS}

The authors studied and analyzed international legal acts, Ukraine's legislation, and scientific publications on domestic violence. The method of statistical processing of analytical data of the World Health Organization (hereinafter - WHO), the Institute of Demography and Social Research at the request of the UN Population Fund, the Ministry of Social Policy of Ukraine, the Ministry of Internal Affairs and the Prosecutor General's Office of Ukraine. In particular, empirical materials on domestic violence complaints in Ukraine for 2017 - the first half of 2020 and data on the number and types of criminal offenses related to domestic violence in Ukraine in 2013, 2017, and 2018 were studied and processed. A survey of 1,800 respondents in Ukraine aged 18 and older was analyzed according to a nationally representative sample conducted by experts from the United Nations Population Fund on the forms, types, and ages from which respondents faced domestic violence. A comparative research method was also useful in comparing the number of cases of violence in Ukraine and Europe during the COVID-19 pandemic, including the number of victims of domestic violence in France in 2018-2019.

\section{REVIEW AND DISCUSSION}

According to Articles 33-40 of the Convention on preventing and combating violence against women and domestic violence (hereinafter referred to as the Istanbul Convention), there are nine domestic violence forms. But eight of them have been identified as criminalized, including "psychological violence"; "persecution"; "Physical violence"; "Sexual violence, including rape"; "Forced marriage"; "Female genital mutilation"; "Forced abortion and sterilization" and "sexual harassment". Domestic violence is characterized by increased social danger, as it causes significant damage not only to the life and health of family members but also to social relations in the field of family and child-rearing. In November 2011, Ukraine acceded to the Istanbul Convention of the Council of Europe, but only on December 6, 2017, the Verkhovna Rada of Ukraine adopted the law "On Amendments to Certain Laws of Ukraine following Ratification of the Council of Europe Convention on Preventing Violence against Women and Domestic Violence and combating these phenomena" [4].

According to this Law, the Criminal Code of Ukraine was supplemented with a new article number $126^{1}$ "Domestic Violence" as follows: "intentional, systematic commission of physical, psychological or economic violence against a spouse or former spouse or another person with whom the perpetrator is (was) in the close family relationship, which leads to physical or psychological suffering, health disorders, disability, emotional dependence or deterioration of the quality of life of the victim." Of course, this is a favorable decision because domestic violence cases were silenced or ignored by society and the state. They were considered an internal problem for a long time and, therefore, turned into latent offenses. Recently some attention to this socio-legal severe 

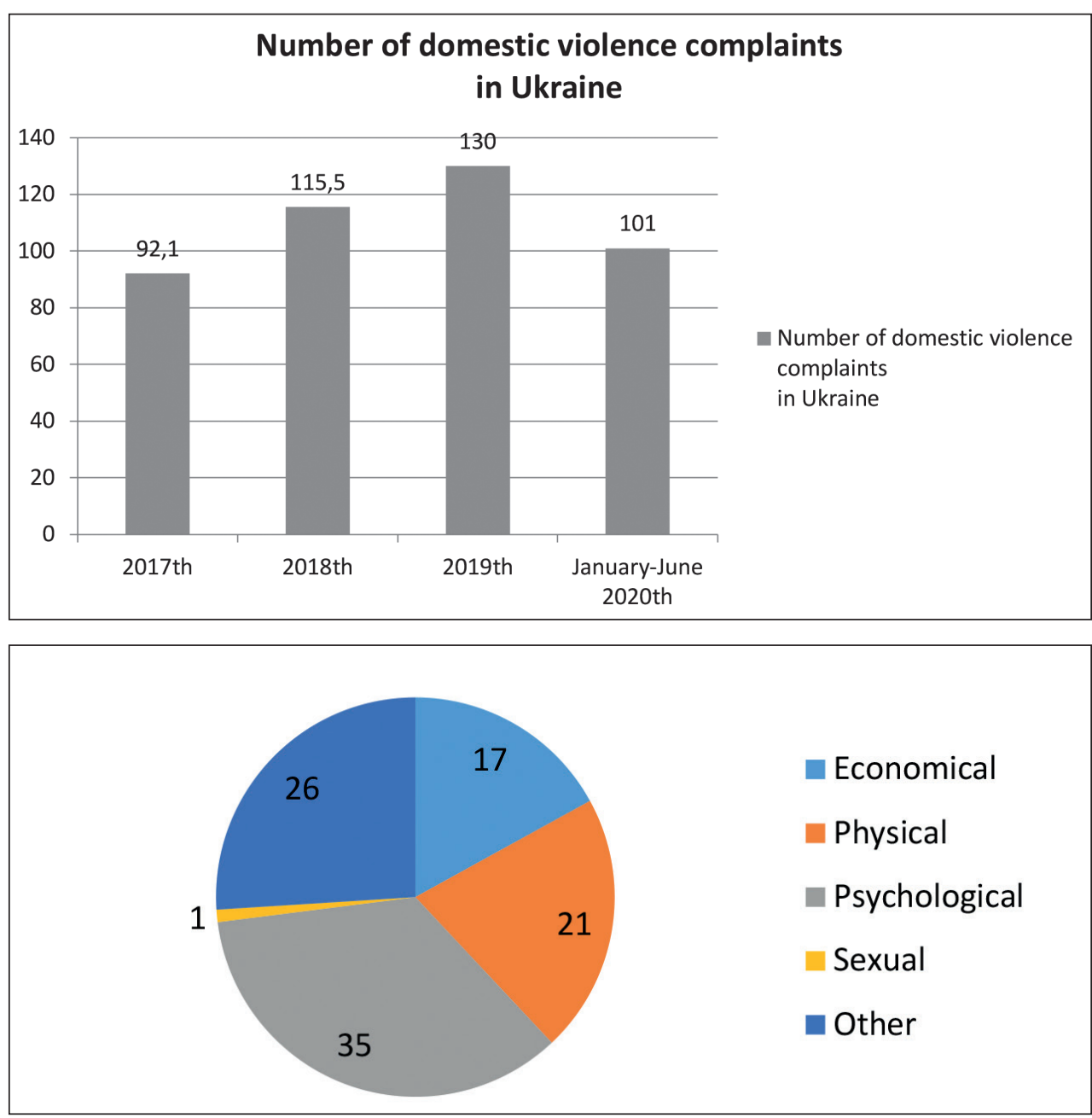

Fig. 1. Number of domestic violence complaints in Ukraine

Fig.2. Forms and amount of domestic violence in Ukraine problem has been drawn because these actions committed by members of their own families cause more severe psychological and physical harm than actions by third parties.

The family is an important social and legal institution of the state and society, determined by a set of social norms and patterns of behavior that constitute the socio-legal cell of society and the state. Sociologists argue that the family is a kind of microsocial community of people that performs extremely important functions that any other social and legal structures are unable to perform $[1$, p. 52] and is therefore recognized as an invaluable treasure that builds our identity from an early age and gives us a sense of security and care [20, p. 175]. Depending on the spheres of life, the following main functions of the modern family are distinguished: socializing, reproductive (demographic), educational, economic, primary social control, spiritual communication, and others. [2, p. 14-16]. Therefore, it is fair to say that when a family is strong, a state is strong too. The moral and psychological state of society depends on the moral and psychological "health" of the family. In particular, domestic violence is the most socially dangerous and deviant behavior of its members, as it violates the basic principle of family life - the safe and comfortable existence of each member [3].

According to statistics, more than 3 million children in Ukraine witness domestic violence every year, and almost
$70 \%$ of women experience various forms of abuse and humiliation from men. Every year, about 1,500 women die from violence by their own husbands, and this trend has been increasing for the past three years. In general, according to statistics, every second person in our country has experienced domestic violence, and the number of appeals to law enforcement agencies over the past five years has increased by almost 34\% (from 110 to 165 thousand) $[5$, p. 4].

In particular, the Minister of Social Policy at the UNFPA International Forum "Ukraine on the Way to Overcoming Domestic and Gender-Based Violence" pointed out that one in five women in Ukraine faces various domestic violence forms. Men are not an exception, but $90 \%$ of victims of violence are women. During 2019, more than 130 thousand domestic violence complaints were registered, of which - 88\% from women, $10 \%$ - from men, $2 \%(1,055$ complaints) from children, which is $15 \%$ more than in the same period last year [21]. Accordingly, in 2017, these figures were 92.1 thousand, and in 2018 - 115, 5 thousand [22] (Fig.1).

According to the Prosecutor General's Office of Ukraine, at the end of December 2019, 2,554 criminal offenses related to domestic violence were registered, and in May 2020 , their number increased by $69 \%$ compared to the same 
Table 1. Number and types of criminal offenses related to domestic violence in Ukraine in 2013

\begin{tabular}{cc}
\hline Intentional homicide & $\mathbf{5 5}$ \\
\hline Intentional homicide, in excess of the limits of necessary defense & 4 \\
\hline Negligent manslaughter & 2 \\
\hline Incitement to suicide & 2 \\
\hline Intentional grievous bodily harm & 120 \\
\hline Intentional moderate bodily injury & 83 \\
\hline Intentional minor bodily injury & 1019 \\
\hline Beatings and cruel treatment & 97 \\
\hline Torture & 3 \\
\hline Threat of murder & 28 \\
\hline Unlawful deprivation of liberty & 3 \\
\hline Regligent severe or moderate bodily injury & 3 \\
\hline
\end{tabular}

Table 2. Number and types of criminal offenses related to domestic violence in Ukraine in 2017

\begin{tabular}{ccc} 
& Grave and especially grave crimes & 172 \\
\hline Intentional minor bodily injury & 592 & 92 \\
\hline Intentional grievous bodily harm & 92 \\
\hline
\end{tabular}

Table 3. Number and types of criminal offenses related to domestic violence in Ukraine in 2018

\begin{tabular}{ccc}
\hline Grave and especially grave crimes & 179 & 699 \\
\hline Intentional minor bodily injury & 88 \\
\hline Intentional grievous bodily harm & 889 \\
\hline
\end{tabular}

period last year [23], and the number of deaths in Ukraine as a result of domestic violence last year - 777 people, 305 of whom - children [24]. During the six months of 2020 in Ukraine, more than 101 thousand applicants have already applied to the police for domestic violence, which is $40 \%$ more than last year [25].

Experts from the United Nations Population Fund surveyed 1,800 respondents in Ukraine aged 18 and older, which showed that $44 \%$ of Ukraine's population had experienced domestic violence during their lifetime, with $30 \%$ of them suffering from domestic violence during childhood. About half of those who have been victims of childhood violence have encountered it in adulthood. Besides, experts from the United Nations Population Fund noted that women were more likely to experience domestic violence in adulthood (33\% vs. $23 \%$ of men) and men in childhood ( $34 \%$ vs. $27 \%$ of women); $35 \%$ of Ukrainians have experienced psychological violence (most often constant humiliation and controlling behavior), $21 \%$ with physical (beating, as well as locking, tying, forcing to stand still), $17 \%$ - with economic (forcing to report for every penny, misappropriation or destruction of property), $1 \%$ - with sexual violence (forced sexual intercourse) [26] (Fig. 2).

According to research, domestic violence not only destroys harmony in the family and causes family unhappiness, leads to resentment and hatred of family members, but also often is one of the prerequisites for the spread of crime in society, and can become even a constant criminogenic factor. Thus, $23 \%$ of serious violent crimes are committed directly in families [6, p. 273 - 280] (Table 1,2,3).

Calculations made by the Institute of Demography and Social Research for the United Nations Population Fund show that 1.1 million Ukrainian women face physical and sexual aggression in the family each year, but most of them conceal such facts [10]. Domestic violence in Ukraine is the cause of 100,000 days of hospitalization, 30,000 calls to trauma departments, and 40,000 calls to doctors. Simultaneously, only $10 \%$ of domestic violence victims seek professional help [9]. After all, many people still consider such relations to be "normal". In fact, various spheres of human existence are filled with violence. Unfortunately, it has become the norm of people's lives.

As Polish experts rightly point out, the manifestations of domestic violence in the family environment do not actually depend on culture, religion, environment, education, intellectual level of a person or belonging to a social group. But without a doubt, domestic violence, they believe, is a degrading form of behavior, always breaking the law, and often causing physical injury. Moreover, mainly domestic violence is not manifested in one-time actions, but is committed over a long period of time and tends to increase [11, p. 24].

Therefore, according to Polish scholars, domestic violence is a deliberate act based on a significant predomi- 
nance of forces and directed against family members, which not only violates personal rights but also causes suffering and injury and is usually directed against women, children, older people, as well as sick family members [12, p. 14]. Besides, domestic violence, as Polish scholars rightly recognize, also harms the dignity and fundamental rights and freedoms of family members [11, p. 23].

The consequences of domestic violence for women are often severe and tragic, as they lead not only to physical damage to health but also to irreversible emotional disorders. They often develop a complex post-traumatic stress syndrome, which manifests itself in states of excessive arousal $[11$, p. 33]. Such a woman may also suffer from insomnia and experience constant fatigue or anxiety, which makes her emotionally unstable, panic attacks, or becomes irritable and nervous. Also, domestic violence victims are characterized by depressive states, which are accompanied by passivity, feelings of helplessness, problems with concentration and memory, and others. In fact, such women lose faith in themselves, and in the future, they cannot make their own decisions and feel helpless. Women victims of domestic violence do not believe in their own strength and believe that it is impossible to stop violence from a partner. Therefore, among the victims of domestic violence, there may be a tendency to the self-destruction of the individual, the manifestations of which are: alcohol, drugs, suicide attempts. In particular, about $10 \%$ of women victims of domestic violence try to commit suicide [11, p. 36-37].

No less alarming is the number of children affected by domestic violence in Ukraine, almost $60 \%$ of children aged 2 to 14 suffer from psychological or physical violence in the family. Such preliminary results of the study were announced by the Head of the UNICEF Office in Ukraine Yukie Mokuo at the international conference "Assistance to Victims of Violence" [27]. The medical literature indicates that most patients treated for post-traumatic stress disorder (PTSD) are victims of domestic violence, especially if it is experienced in childhood, have psychological problems such as affective lability, impulsivity, aggressive behavior towards themselves and other people, dissociative symptoms, constant feelings of guilt or shame [12, p. 39].

According to researches, if a child has experienced domestic violence at least four times, the risk of suicide increases to 49 times [7]. Besides, such children are six times more likely to commit suicide, and about $50 \%$ start using drugs. Almost $100 \%$ of mothers who have experienced domestic violence have given birth to sick children - mostly with neurosis, stuttering, enuresis, cerebral palsy, mental disorders [8]. Therefore, the consequences of domestic violence for children, regardless of whether it has been applied to them or if they have only witnessed it, according to Polish experts, harm their health and development. In particular, this can manifest itself in negative consequences for the emotional state, which without the intervention of specialists can lead to low self-esteem; fear; stress; a state of excessive arousal or apathy; self-destruction of the individual; criminal and anti-social activities; poor learning outcomes; bad relationships with peers; isolation from society; distrust; aggression. Domestic violence also harms a minor's health, which can lead to several psychosomatic symptoms; complex disorders after traumatic stress disor$\operatorname{der}(\mathrm{C}-\mathrm{PTSD})$ [15, p. 42].

In addition, such children become aggressive in the future and use violence in their own families to their children and family members because they copy their parents patterns of behavior [16, p. 51]. Children who grow up in a family where there was violence constantly live with a sense of danger, they hide and suppress their feelings, try to cope with despair and helplessness, feel lonely both in the family and outside it [17, p. 148].

Minors who have witnessed or been victims of domestic violence may have difficulty understanding love and normal family relationships in the future. Researchers of this problem claim that domestic violence can manifest itself in the transgenerational inheritance of images that they received in their childhood [17, p. 149]. Therefore, children who are domestic violence victims may develop psychophysical disorders, such as disability, emotional and mental disorders. In the future, such individuals will not always be able to adapt to the environment, they seek to isolate themselves in interpersonal relationships, and may even commit suicide, because the neurohormonal system undergoes irreversible changes that significantly reduce the child's resistance in affective situations [18, p. 48].

It is not for nothing that doctors and psychologists recognize domestic violence as a particularly traumatic experience that causes irreversible and long-lasting consequences in the victim's mental life. It can even change a person completely $[19, \mathrm{p} .40]$ and can manifest itself in: low self-esteem, deep distrust of people, especially men, difficulties in domestic relations, leading a satisfactory sex life [19, p. 43-44]. However, doctors note that most often, domestic violence facts are silenced and hidden by both parties [5, p. 9-10]. Therefore, to recognize one of its forms in the form of physical violence against family members, including minors, despite the symptoms, it is difficult even for an experienced doctor, pediatric surgeon because victims of such violence usually do not provide reliable data, about the mechanism of injury or call false data about their receipt [14, p. 45].

Another dangerous type of domestic violence, along with physical, is psychological. According to research by doctors and psychologists, in such cases, its victims are very likely to identify himself/herself with the offender, which is a reaction to the situation and was called the Stockholm syndrome because the victims are willing to act in offenders' interests. However, in such cases, the aggressor may require the woman not only to submit but also to make her like such submission. According to experts, "the primary goal of the perpetrator of violence is to enslave the victim. He achieves his goal by exercising despotic control over every aspect of the victim's life. "However, submission in itself rarely satisfies him; most of the perpetrators have a psychological need to justify their behavior, and for that, they need the full consent of the victim [11, p. 37-38]. Humiliation, unfair, cruel treatment, which is one of the 
manifestations of domestic violence, can leave their mark on the emotional structure of the individual and, under certain conditions, generate appropriate, deviant behaviors $[29$, p. 51]. According to doctors, even mentally healthy people often develop mental disorders after the violence, which is an acute reaction to domestic violence, such as post-traumatic stress disorder, adaptation disorders, depressive disorders, behavioral disorders, etc., which are also considered harmful to health - his mental function [29, p. 44]. Therefore, most of the research on domestic violence is consistent with the statement that aggression and cruelty in the future can be mastered in the parental family [29, p. 52]. Thus, assistance to domestic violence victims always requires rehabilitation from its negative consequences and should be addressed in conjunction with representatives of many fields: medicine, psychology, pedagogy, sociology, ethics, law, economics, and others. [14, p. 47].

\section{CONCLUSIONS}

Domestic violence is a socially dangerous act that negatively affects family members because it causes significant damage to health and life. The consequences of domestic violence are the most dangerous for both the physical and mental health of women and minors, as they are particularly vulnerable to it.

In order to protect victims of domestic violence, the Criminal Code of Ukraine was amended by Art. $126^{1}$ of the Criminal Code and Section XIII-1 "Restrictive measures" and considered as positive by us. However, it is extremely important to address the harmful effects of violence against family members.

Based on this, we believe that rehabilitation is one of the ways to solve this problem, which minimizes the consequences of domestic violence. Doctors are often among the first to be approached by a victim of violence. Of course, in this case, it depends on them will they be able to provide not only the necessary medical care but also to support the victim morally and psychologically, to evoke and strengthen victims' self-confidence, and to direct them for further social and legal assistance. In particular, the medical and social rehabilitation center is called upon to overcome domestic violence's consequences. Its activity is aimed at restoring and preserving psychophysiological functions, optimal working capacity, and the level of social functioning of violence victims.

Therefore, the rehabilitation of domestic violence victims is a necessary and vital measure, as it helps restore the health of the victim, save lives and resocialize a person as much as possible. Only then will we be able to achieve the idea of sustainable development of the family, its quality and balanced life as members of the family, society, and the state.

\section{REFERENCES}

1. Bajdalakina A. Teoretychni problemy vyznachennia poniattia «sim'ia» v umovakh rozvytku suspil'nykh nauk [Theoretical problems of defining the concept of "family» in the development of social sciences]. Pidpryiemnytstvo, hospodarstvo, pravo. 2007;3:52 - 55 (Ua).

2. Romovs'ka Z.V. Ukrains'ke simejne pravo: pidruchnyk [Ukrainian family law: a textbook]. Kiev: Pravova iednist', 2009.500 s. (Ua).
3. Poyasnyuval'na zapyska do proektuZakonu Ukrainy "Pro zapobihannia ta protydiiu domashn'omu nasyl'stvu" [Explanatory note to the draft Law of Ukraine "On Prevention and Counteraction to Domestic Violence"]. Available from: w1.c1.rada.gov.ua/pls/zweb2/webproc34?id...46129. [reviewed: 2020.08.11] (Ua).

4. Zakon Ukrainy «Pro vnesennia zmin do Kryminal'noho ta Kryminal'noho protsesual'noho kodeksiv Ukrainy z metoiu realizatsii polozhen' Konventsii Rady Yevropy pro zapobihannia nasyl'stvu stosovno zhinok i domashn'omu nasyl'stvu ta borot'bu z tsymy iavyschamy [0n Amendments to the Criminal and Criminal Procedure Codes of Ukraine in order to implement the provisions of the Council of Europe Convention on Preventing and Combating Violence against Women and Domestic Violence]. Vidomosti Verkhovnoi Rady (VVR). 2018; 5: 34 (Ua).

5. Nasyl'stvo: korotkyj instruktazh dlia konsul'tantiv ta konsul'tantok [Violence: briefing for counselors]. MBF «Al'ians hromads'koho zdorov'ia». Kyiv. 2017. 35 s. (Ua).

6. Drozdova I.V. Nasyl'stvo v sim'y yak odna iz determinant deviantnoy povedinky ditej ta molodi [Domestic violence as one of the determinants of deviant behavior of children and youth]. Naukovyj visnyk L'vivs'koho derzhavnoho universytetu vnutrishnikh sprav. Seriia iurydychna. 2011;2:273-280 (Ua).

7. VOOZ i Minokhorony zdorov'ia opryliudnyly shokuiuchi dani schodo nasyl'stva nad dit'my [WHO and Ministry of Health issue shocking data on violence against children]. Available from: https: www.5.ua/ suspilstvo / V00Z ta Minokhorony-zdorovia-opryliudnyly-shokuiuchi-dani-shchodonasylstva-nad-ditmy--161165.html. [reviewed: 2020.08.17] (Ua).

8. Bulinh: zovnishnist', povedinka, uspikhy ta statky rodyny - mozhut' staty prychynamyts'kuvannia dytyny [Bullying: the appearance, behavior, success and wealth of the family - can be the cause of child abuse]. Available from: http://vinnitsaok.com.ua/archives/911830 [reviewed: 2020.08.11] (Ua).

9. Pro scho zazvychaj ne rozkazuiut' navit' blyz'kym [What is usually not told even to relatives.]. Yurydychna hazeta vid 24 hrudnia 2019. Available from: https://yur-gazeta.com/publications/practice/ simeyne-pravo/pro-shcho-zazvichay-ne-rozkazuyut-navit-blizkim. html [reviewed: 2020.08.18] (Ua).

10. Metodychni rekomendatsii schodo zapobihannia ta protydii nasyl'stvu [Guidelines for preventing and combating violence]. Available from: https:// zakon.rada.gov.ua/rada/show/55480729-18 [reviewed:2020.08.18] (Ua).

11. Agnieszka Woźnica Przemoc wobec kobiet w rodzinie. Warszawa 2007. 55 s. Available from:https://cpk.org.pl/wp-content/uploads/2017/09/ niezbednik_pracodawcy.pdf [reviewed: 2020.08.18].

12. Helios J., Jedlecka W. Współczesne oblicza przemocy. Zagadnienia wybrane. Wrocław 2017. Available from: https://www.repozytorium. uni.wroc.pl/Content/80015/Wspolczesne_oblicza_przemocy.pdf [reviewed: 2020.08.11].

13. COVID-19:VYevropi pid chas karantynu pobil'shalo skarh na domashnie nasyl'stvo [Complaints of domestic violence increased in Europe during quarantine]. Available from: https://www.dw.com/uk/covid19-v-ievropi-pid-chas-karantynu-pobil'shalo-skarh-na-domashnienasyl'stvo/a-53364233 [reviewed: 2020.08.30] (Ua).

14. Bibiana Mossakowska Społeczno-medyczne aspekty Zespołu Dziecka Maltretowanego. Od Hipokratesa i Platona do współzzesności. BIULETYN RZECZNIKA PRAW OBYWATELSKICH 2010. № 3. ŹRÓDŁA Konferencja Rzecznika Praw Obywatelskich «Przeciw przemocy domowej. Ręce są do przytulania» 22 lutego 2010 r. Warszawa. Available from: https://www. rpo.gov.pl/sites/default/files/Biuletyn_RPO_Konferencja_Rzecznika_ Praw_Obywatelskich_Przeciw_przemocy_domowej_Rece_sa_do_ przytulania_-_22_lutego_2010_r..pdf [reviewed: 2020.08.30]. 
15. Renata Durda Kierownik Ogólnopolskiego Pogotowia dla Ofiar Przemocy w Rodzinie „Niebieska Linia” Dzieci w relacjach przemocowych jako ofiary, świadkowie lub sprawcy przemocy. Biuletyn rzecznika praw obywatelskich 2010. № 3 Źródła Konferencja Rzecznika Praw Obywatelskich «Przeciw przemocy domowej. Ręce są do przytulania» 22 lutego 2010 r. Warszawa. Available from: https://www.rpo.gov. pl/sites/default/files/Biuletyn_RPO_Konferencja_Rzecznika_Praw_ Obywatelskich_Przeciw_przemocy_domowej_Rece_sa_do_przytulania_-_22_lutego_2010_r..pdf [reviewed:2020.08.30].

16. Konrad Wojterkowski Budowanie świadomości społecznej na przykładzie kampanii «Kocham. Nie biję» i "Kocham. Reaguję». Biuletyn rzecznika praw obywatelskich 2010. № 3 Źródła Konferencja Rzecznika Praw Obywatelskich «Przeciw przemocy domowej. Ręce są do przytulania» 22 lutego 2010 r. Warszawa. Available from: https://www. rpo.gov.pl/sites/default/files/Biuletyn_RPO_Konferencja_Rzecznika_ Praw_Obywatelskich_Przeciw_przemocy_domowej_Rece_sa_do_ przytulania_-_22_lutego_2010_r..pdf [reviewed:2020.08.11].

17. Józef Młyński Przemoc w rodzinie - skala zjawiska, ofiary przemocy i formy pomocy pracowników socjalnych. Studia Socialia Cracoviensia 4 2012); 2 (7).

18. Uniwersytet Medyczny w Białymstoku Wydział Nauk o Zdrowiu różne barwy przemocy Tom I Praca zbiorowa pod redakcją Prof. dr hab. n. med. Elżbiety Krajewskiej-Kułak Dr n. med. Krystyny Kowalczuk Lek. Agnieszki Kułak-Bejda Dr n. o zdr. Andrzeja Guzowskiego Prof. dr hab. n. med. Wojciecha Kułaka Białystok 2016. Available from: https://www. umb.edu.pl/photo/pliki/Dziekanat-WNOZ/monografie/11-2016/6.pdf [reviewed: 2020.08.11].

19. Agnieszka Filipek Wspomaganie człowieka dorosłego w sytuacji przemocy w rodzinie Praca doktorska napisana pod kierunkiem dr hab. Małgorzaty C. Halickiej, prof. UwB Białystok 2017. Available from: https://repozytorium.uwb.edu.pl/jspui/bitstream/11320/7114/1/A Filipek_Wspomaganie_czlowieka_doroslego_w_sytuacji_ przemocy_w_rodzinie.pdf [reviewed: 2020.08.11].

20. Milena Mikielewicz1 przemoc psychiczna w rodzinie - globalne wyzwanie zrównoważonego rozwoju. Eunomia 1(94). 2018: 169-176. Available from: http://yadda.icm.edu.pl/yadda/element/bwmeta1. element.desklight-6a79b7c5-8c41-4ae2-90c0-7aa86e793a16 [reviewed: 2020.08.11].

21. Sokolovs'ka Yu. Kozhna p'iata zhinka v Ukraini stykaiet'sia z tiieiu chy inshoiu formoiu nasyl'stva [Every paid woman in Ukraine faces some form of violence]. Available from: https://www.msp.gov.ua/ news/18311.html [reviewed: 2020.08.17] (Ua).

22. Minsotspolityky spil'no z Ministerstvom iustytsii ta Ministerstvom vnutrishnikh sprav aktyvizovuiut' robotu zi stvorennia reiestru kryvdnykiv, iaki vchynyly domashnie nasyl'stvo, nasyl'stvo za oznakoiu stati abo inshi formy nasyl'stva stosovno postrazhdaloi osoby [The Ministry of Social Policy, together with the Ministry of Justice and the Ministry of the Interior, is stepping up efforts to establish a register of perpetrators of domestic violence, genderbased violence or other forms of violence against victims]. Available from: https://www.msp.gov.ua/news/18191.html?PrintVersion [reviewed: 2020.08.17] (Ua).

23. Pro zareiestrovani kryminal'ni pravoporushennia ta rezul'taty ikh dosudovoho rozsliduvannia [About the registered criminal offenses and results of their pre-judicial investigation]. Available from: https://old. gp.gov.ua/ua/stst2011.html?dir_id=113897\&libid=100820\&c=edit\&_ $c=f_{0}$ [reviewed: 2020.08.05] (Ua).
24. U 2019 rotsi v Ukraini vid domashn'oho nasyl'stva zahynulo 777 osib [In 2019, 777 people died in Ukraine from domestic violence]. Available from: https://dyvys.info/2019/12/19/u-2019-rotsi-v-ukrayini-viddomashnogo-nasylstva-zagynulo-777-osib/[reviewed:2020.08.05] (Ua).

25. Kil'kist' skarh na domashnie nasyl'stvo zrosla na $40 \%$. Tse ponad sto tysiach za piuroku [The number of complaints of domestic violence increased by $40 \%$. That's over a hundred thousand in six months]. Available from: https://hromadske.ua/amp/posts/kilkist-skarg-nadomashnye-nasilstvo-zrosla-na-40-ce-ponad-sto-tisyach-viklikiv-zapiv-roku [reviewed: 2020.08.11] (Ua).

26. 00N: Domashnie nasyl'stvo v Ukraini [UN: Domestic Violence in Ukraine]. Available from: http://www.hearts.in.ua/articles/againstdomestic_violence/623.php. [reviewed: 2020.08.11] (Ua).

27. $60 \%$ ukrains'kykh ditej strazhdaiut' vid nasyl'stva u sim'i [60\% of Ukrainian children suffer from family violence] Available from: $\mathrm{https}$ :// zaxid.net/60_ukrayinskih_ditey_do_14_rokiv_strazhdayut_vid_ nasilstva_v_simyi_n1283817/amp. [reviewed: 2020.08.05] (Ua).

28. U Frantsii torik zrosla kil'kist' zhertv domashn'oho nasyl'stva [In France, the number of victims of domestic violence increased last year]. Available from: https://www.eurointegration.com.ua/ news/2020/08/18/7113331/index.amp. [reviewed:2020.08.11] (Ua).

29. Onyshko Yu. V. Medyko-sotsial'na dopomoha ditiam, iaki zaznaly nasyl'stva v sim'i: Prohrama tsyklu tematychnoho vdoskonalennia likariv [Medical and social care for children who have experienced domestic violence: The program of the cycle of thematic improvement of doctors]. Kiev : TOV «K.I.S.», 2010. 120 s. (Ua).

\section{ORCID and contributionship:}

Oksana O. Volodina: 0000-0003-3211-0303 A,B,D

Viktoriia V. Haltsova: 0000-0002-0700-427X ${ }^{A, B, D}$

Sergiy O. Kharytonov: 0000-0002-8947-8734 ${ }^{\mathrm{A}, \mathrm{E}, \mathrm{F}}$

\section{Conflict of interest:}

The Authors declare no conflict of interest.

\section{CORRESPONDING AUTHOR}

\section{Sergiy $\mathbf{0}$. Kharytonov}

Yaroslav Mudryi National Law University Kharkiv, Ukraine

tel: +380503233980

e-mail: kharitonovs@ukr.net

Received: 24.08 .2020

Accepted: 27.11.2020

A - Work concept and design, B - Data collection and analysis, C - Responsibility for statistical analysis, $\mathbf{D}$-Writing the article, $\mathbf{E}$-Critical review, $\mathbf{F}$ - Final approval of the article 